\title{
The IT Industry and Employment in India: A Critical Reassessment
}

\author{
Aabid Firdausi MS
}

Tata Institute of Social Sciences, Mumbai, India, aabidfms@gmail.com

\begin{abstract}
The Indian IT industry has been regarded as a success of neoliberal economic reforms, driven by private initiative and export-oriented growth. Accordingly, employees of the IT industry that are symbolic of the 'new India' are seen as the aspirational new middle class, 'different' from the traditional working class. This article critically examines these claims. Firstly, it is argued that the development of the IT industry should be situated in the context of the larger development of capitalism in India. Secondly, through an analysis of narratives from interviews with workers during a period of industrial restructuring due to geopolitical concerns and technological change, the article attempts to understand workers' perceptions of industrial dynamics as well as possibilities of collective resistance against the logic of capital.
\end{abstract}

Keywords: IT industry, labour, class, unions, India

\section{Introduction}

The Indian IT/ITeS industry (henceforth IT industry) that has marked its presence in the global market since the 1990s has been regarded as a success of neoliberal economic reforms. The industry is symbolic of a 'new India' with employees themselves becoming ardent "votaries of globalisation" as opposed to representing traditional working class concerns (Upadhya 2004). Following Bell (1976) on the post-industrial society, it is conceived that traditional class relations were no longer applicable to the IT 'professionals' who constituted the new middle class, possessing relatively high purchasing power and enjoying merit-based upward mobility.

Due to the sectoral specificity of workplace relations as well as the content of work (for example, freedom from physical drudgery and engagement with the digital), there has so far been no felt need for collective bargaining via unions. However, one needs to look beyond the "veil of images and discourses that swirl around the industry" and "unpack the ubiquitous narratives" to critically reflect on the celebratory accounts of the IT Industry (Upadhya 2008). An attempt is made in this article to do the same.

There are two ways in which this unpacking is done. Firstly, the IT industry is not studied in isolation, but in relation to the larger capitalist economic transformations in India. This necessitates historically situating the industry within specific developments in contemporary global capitalism. What is called "information/informational capitalism" (Castells 1999; Parayil 2005) is an outcome of the development of productive forces, especially technological change. Hence, the IT industry is a manifestation of advanced capitalism in India, albeit caught in an asymmetric (imperial) relation with the North.

Secondly, we examine whether these subjectivities that supposedly transcend the capitalist-worker binary hold true during times of uncertainty - for example, during structural transformations like those precipitated by rapid technological changes in 
the industry. What is the possibility of solidarity during times of hardship (Stevens and Mosco 2010) and how do workers react to technological changes in the production process over which they have little control? In specific terms, do concrete material conditions have an impact on the way employees think and feel about the industry, and possibly lead to a change in the way they articulate their class positions?

This article sets out to explore the first question by examining the nature of the IT industry by borrowing insights from critical political economy. The question is approached by examining the class relationships that changed with the nature of the state in neoliberal India, since the IT industry's growth phase has been closely related to this new phase of global capitalism. The phase of structural transformation that the industry is moving through due to geopolitical changes as well as technological advancements is highlighted in relation to these capitalist processes.

The second question of understanding worker responses to new forms of automating technology is examined based on detailed interviews with employees of an IT park in Kerala (a state in South India). Fieldwork was done during a time when the IT sector was in a transition phase and experiencing a slowdown with low employment generation. Kerala has a unique history of active labour movements, but the IT Park exists as a pocket of deviation from the militant strategies of trade unions. The article attempts to understand workers' perceptions of industrial dynamics, as well as possibilities of collective resistance against the logic of capital.

\section{Unpacking the Myth}

It is historically inaccurate to view the neoliberal phase of Indian capitalism to be systemically disconnected from the dirigiste period. While it is certainly true that the post-1990s phase has seen a radical departure from this period especially in the role of the state, it is more analytically fruitful to understand the former as an organic evolution of the latter. This means that one should see the origins of neoliberalism not just in the transition from pro-business reforms to pro-market reforms, as Rodrik and Subramanian (2005) argue, but in the systemic contradictions of having sustainable public investment in capitalist India that has become increasingly globalised since the late 1970s. Understanding such linkages between the 'old' and the 'new' helps us to develop a holistic picture of Indian capitalism that is important both in a theoretical and a strategic sense.

The neoliberal slogan that 'there is no alternative' to the hegemony of capital lent credence to this gradual transition. The neoliberal phase of Indian capitalism is thus witness to a change in class relations in India, as the New Economic Policy involved the dilution of the regulatory regime, and labour politics was to take new dimensions, with a general decline of militancy. Situating the IT industry within this transition phase of Indian capitalism explains why it is celebrated in neoliberal circles - the industry is export-oriented, dominated by the private sector, and has a disciplined workforce.

However, the industry did not emerge merely due to private initiative but due to a host of public investments, especially in technical education during the dirigiste period (see Parthasarathy 2005; Saraswati 2008; 2013), and the computerisation drive in sectors like banking and the telecom revolution during the 1980s. This means that the state played a proactive role in the (re)production of digital labour commodified in the global IT industry. This continued during the neoliberal phase, for example through the provision of infrastructure, and the allocation of land, water, electricity, and other services like financial subsidies and tax concessions. Thus, the 
industry has been able to successfully cultivate a developmental association with the state, which other industries were unable to do (Barnes 2013).

Despite the celebration of IT in policy in public discourse, the industry has done relatively little to alleviate socioeconomic disparities and lead the trajectory of economic development. The relative absence of a domestic market, specialisation in software services that have few spinoffs compared to hardware manufacturing, and the absence of diversification in export market has led D'Costa (2005) to call it a "decoupled development" similar to the export enclaves of the colonial period. Due to this 'decoupled' nature, it has also been argued that the industry is not as robust as it seems. This is examined in the following section.

\section{Structural Transformations}

The global IT industry is characterised by a transnational capitalist class (Upadhya 2004) and a transnational labour regime (Xiang 2005). The Indian IT industry made its presence significant in the global IT landscape with its effective handling of the Y2K crisis, and has since registered consistent growth rates. The domestic industry is segmented into services, products, e-commerce and hardware, where services predominate (NASSCOM 2018). The industry has a pyramidal structure with a few large firms and a large number of small and medium enterprises, creating a tiered hierarchy of value generation. Depending on exports rather than domestic demand also makes the industry vulnerable to global economic downturns, which was most notable during the global recession of 2008.

The year 2016-17 witnessed two unprecedented developments - one, the changes in global geopolitics that fostered sentiments of anti-globalisation largely through protectionist rhetoric by the US as well as other European countries, and two, adoption of new technologies that included the automation of certain labourintensive tasks (Narayan 2017). Indian IT depends heavily on the US for its visafriendly policies and also because the US accounts for $60 \%$ of Indian IT exports (Ministry of Electronics and Information Technology 2017). This reiterates the decade-old demand that the industry should diversify its client market and depend more on markets like Japan. However, the industry has had little success in reducing excessive dependence on markets in the US and Europe. While the shock due to changes in global state policies can be mitigated to some extent, the technological wave is more organic and hence endogenous to capitalist development. It is this aspect that this article focuses on.

Automation has existed in less pronounced forms since the industry's inception, and employees have always had to adjust themselves to changes in work processes. Yet the present technological wave has made several structural transformations in the way the software sector operates in the country: these will play a decisive role in the future of work in the industry. Firstly, Indian IT's labour absorption phase, wherein the company's revenues depended on the number of employees hired, has come to a halt (Chandrasekhar and Ghosh 2017). Industry reports stress that the linear pricing model, where there was a "proportionate increase in headcount to augment revenue", is neither desirable nor sustainable compared to the non-linear pricing model that links "client expenses to business outcomes or usage instead of headcount and effort spent" (KPMG 2011). This means it is likely that there will be a reorientation in the global labour arbitrage (or the new international division of labour) that formed the foundation for Indian IT industry (Lakha 1994).

Secondly, the adoption of cloud computing allows companies to move their data to online shared storage. This affects the revenue generation model of Indian IT 
service providers that are engaged in conventional IT infrastructure management, as clients can now rent their required infrastructure from cloud service providers (Narayan 2017).

Thirdly, the usage of automating technologies in the industry is set to increase in upcoming years. Prior to the adoption of automating technologies, the labour process in projects handled by the global software industry was divided into four phases: specifying software requirements; designing software; coding/testing; and delivery and installation (Ilavarasan 2008). The first two high value-adding phases are handled in the advanced capitalist countries, while the other two are outsourced (2008). Testing is a function that was particularly labour intensive but is now handled by software.

These developments are seen as part of a phase of capitalism called knowledge or information capitalism, where the production process is digitalised. This has been interpreted as a rupture with industrial capitalism (Parayil 2005). While this is true to some extent, it should not distract us from the continuous development of productive forces under capitalism. This is not a teleological assertion, but has more to do with how technology has developed across space and time. With the development of technology and communication benefiting capital, the IT industry therefore constitutes a step forward in this direction. Fuchs and Sandoval (2014) argue that this phase marks the advent of a digital mode of production that involves a "network of agricultural, industrial and informational forms of work", following which we can argue that the sector marks the advanced segment of Indian capitalism.

But what is crucial here is that technologies do not emerge out of a vacuum; they are an outcome of the social relations of production. These socially produced technologies are privately appropriated: a process which is emblematic of the logic of capitalism. Global capitalism develops by appropriating the 'local' in specific ways, leading to different development trajectories. This can be due to resource endowments, state policy or the availability of reserves of labour. Indian IT's role in the global industry remains that of a service provider to the global North with little value addition. This has been interpreted as a form of imperialism due to the international division of digital labour (Fuchs and Sandoval 2014).

These structural transformations have major implications for labour in the Indian IT industry. It has been argued that the traditional capital-labour relationship has been challenged due to the nature of work dependent on immaterial labour (Amorim 2014), which makes workers neither blue-collar nor white-collar but 'no-collar' (Fuchs and Sandoval 2014). A distinction is drawn between manual and mental labour, and hence class politics is considered to be irrelevant. The individual employee negotiates with the management (Upadhya 2007), and hence it has been argued that there is no prospect for collective bargaining. It can be seen that efforts were undertaken to mobilise employees of the BPO sector since the mid-2000s (Remesh 2008) which met with some success.

However, what is the possibility of solidarity in the midst of economic hardship (Stevens and Mosco 2010)? In other words, do workers articulate their class positions during times of uncertainty? These questions are explored in the sections below by analysing the narratives from interviews of stakeholders including managers and employees in Technopark in Thiruvananthapuram.

\section{IT in Kerala}

Though the IT industry is remarkably global in its operations, we need to contextualise it in relation to the field in question, which is an IT park in Kerala. 
Kerala has a unique political history and is emerging as an IT destination. The presence of organised labour vis-à-vis capital and the state played a decisive factor in Kerala's development experience (Kannan 1998), lauded as the Kerala model of development - where impressive human development indices were achieved at low levels of income. It is crucial to understand that the 'model' existed because of organised class politics that led to a state that was responsive to the demands of labour. The phase of militant class struggle that institutionalised pro-labour policies has given way to one of class compromise, where organised militancy has been diluted to facilitate private enterprise (Heller 1995).

However, strong labour militancy was considered to be a deterrent for private investment (Oommen 1981), leading to unemployment. This was compounded by the lock-in-effect due to early investments in industries that did not generate intersectoral linkages (Thomas 2005a) that could spur domestic industrialisation. However, the early investments in public education and health facilitated labour to take advantage of the oil boom in the Middle East since the 1980s through mass migration, which helped Kerala to mitigate concerns regarding employment to some extent.

It is in this context that we see the IT industry take shape in the state, with the establishment of Technopark, a software technology park, by the Government of Kerala in the capital city of Thiruvananthapuram in 1990. It was hoped that the sector would mitigate the prevalence of educated unemployment, which it did to some extent by providing jobs to around 56,000 people as of $2017-18$. Technopark is the platform employing the largest number of people in the private sector in Kerala. However, the initial trade union response to the introduction of computers was reactionary, due to the widespread fear of labour displacement especially in the telecom industry. Yet such anxieties were quelled as governments including those run by Left parties actively promoted the software sector and consistently supported it after neighbouring states (the Bengaluru-Hyderabad-Chennai silicon triangle) made significant strides in the IT map of India.

It also needs to be noted that the Technopark was first established with linkages to public investments in the electronics sector in the 1970s (by setting up institutes like KELTRON) and not due to private initiative alone. Moreover, IT in Kerala has made remarkable strides in facilitating people-friendly e-governance through projects like Akshaya (Thomas 2005b). Kerala thus charts a different path from the cyberlibertarian view that technological access bridges the digital and developmental divide (Sreekumar 2005) and shows that the potential of ICT diffusion can be realised only by implementing social policies.

Technopark in Thiruvananthapuram, which is the most prominent among the three IT parks in Kerala, has been promoted for its advantages, such as the low cost of living and cost-competitiveness in a Tier - II city, and low levels of attrition (less than 5 percent) compared to national figures (Technopark 2018). The state, irrespective of the political party in power, has lent support to the industry, most recently in the form of land acquisitions and signing contracts with multinationals, so as to develop integrated townships and IT corridors (2018). The industry has attracted two streams of migrant labour - one, to engage in construction activities, and two, to work as employees in the Park. Thus, we see how there is a convergence of different classes to shape the trajectory of a nascent industry that has consolidated domestic and global capital in a rather nondescript region in Kerala. 


\section{Narratives from the Field}

In order to understand worker attitudes in the IT industry and responses to rapid technological changes in particular, semi-structured interviews were conducted among 30 employees in Technopark in the last quarter of 2017, a time which was identified as a crisis period of the Indian IT industry, and snowball sampling was used - hence, there was no predetermined sample size. Thus, "the field defined itself as the research progressed" (Upadhya 2008). This was done initially by conducting informal discussions with immediate contacts, after which the rest of the sample was built. Interviews were held outside the workplaces of the IT parks in Kerala with a view to elicit informal and more honest responses. The interviews were held with industry experts (3), managers (5), employees of startups and service companies (9), newly inducted workers (5), workers whose jobs are becoming redundant (5) and workers who are part of external political organisations (3). Two broad variables are analysed below: responses to structural changes and the socio-spatial distance from non-IT labour that influences prospects for unionisation.

\subsection{Changes in the Industry and Response from Stakeholders}

Contemporary developments in the industry evoked diverse responses from different stakeholders. The contrast between management and employee with regard to the new technologies being used are clearly visible.

Mary, who is an HR Manager at one of the more sought-after companies in Technopark, had this to say about automation: "This is an exciting time for employees, as they are able to learn more about the new technologies through the skilling process". Mary is closely associated with software bodies like NASSCOM and is aware of the latest industry trends. She added that "what is set to happen in the next 5 years is incomparable with what has happened over the past few decades". This newness reflects the scope of technological advancements set to become the norm once Al and other technologies get implemented on a larger scale.

However, this enthusiasm was not shared by most of the employees. For the employees, adjusting and adapting to the new technologies was the only way forward and, though it was imposed from above, they did not resist it, nor did they find the need to challenge it. They unanimously accepted this as the nature of the industry. "Dynamic" is a word that was recurrently used as a label to describe the industry. One respondent, Mahesh, who has work experience of around 15 years in the same company as Mary, made the following statement: "The individual has to sense the market. If he is sleeping, he loses it." This reflects the dynamism of IT technologies that embodies the logic of 'adapt or perish'. Once the individual starts "sleeping", it is the "death of his career".

Abhishek, who has been working in the industry for the past decade, had a less pessimistic view. He metaphorically talked about the employment status of IT employees as follows - "In the age of motorbikes, we still see people who ride cycles. Why? If that is their choice, they will never catch up with the rest of the society". For Abhishek, the employees who find it difficult to cope with changing technologies are responsible for their own plight. They are unwilling to upgrade their skills, and hence they lose out. Abhishek vehemently denied any technological unemployment, much like Mary, who was also very enthusiastic about the forthcoming opportunities. Yet this is a minority opinion, as most of the other employees who were interviewed were of the opinion that the industry's mass labour absorption phase has come to a halt. 
What distinguishes the landscape of IT from other corporate workplaces is the pace at which technologies evolve. It is one of (information) capitalism's greatest contradictions that IT employees who write the code to automate processes in other industries like automobile manufacturing are finding their own jobs threatened. In other words, technological advancements have become the gravedigger of the jobs that they created. The management has been pursuing various strategies to "up-skill and cross-skill" the employees. This includes various formal training programmes in new technologies and more informal techniques like persuasion from immediate authority. However, this is not an easy task during a period of disruptions resulting from technological advancements. Ahmed, who works as an administrator in the same company as Mary and Mahesh, explains this succinctly:

Ideally, what should be done is adoption of new technologies along with actively training the employees on how to use it. What is being followed instead is the adoption of automating technologies without imparting adequate training. This imbalance is what is causing concern among employees. This is also because the management is not well-versed with what is set to happen in the industry and is, hence, clueless as to how to respond to these changes.

Ahmed's explanation sheds light on the pace at which the industry is changing, referred to as the 'automation revolution' or the 'Fourth Industrial Revolution'. This pace of transformation is unprecedented and is often surprising to the developers of these technologies themselves. There are two important points to be noted at this juncture - firstly relating to the individualistic reaction of the average IT employee, and secondly relating to the ethics of developing these technologies:

(a) Despite such structural changes that make the employee more insecure about her/his work, the average IT employee ardently believes that it is the individual's responsibility to navigate through these times of uncertainty. The individual is responsible for keeping himself/herself up-to-date and if they fail to do so for whatever reason, be it legitimate or illegitimate, the company is not really at fault. This represents an internalisation of the logic of private capital, where the individual accepts the inevitability of structures in dictating the patterns of their work. In other words, the employee is powerless to determine the technologies that are being used in the workplace - which reflects a lack of control over the labour process, in stark contrast to the egalitarianism professed by tech companies.

(b) A part of the IT workforce, especially those who are trained in computer science engineering (B.Tech) courses, are actively recruited for writing code. A recurring concern was that there would be job prospects for graduates from this discipline, but not for other disciplines. These graduates, who are skilled in their job, write code so as to serve the cost-cutting needs of the management, which results in the retrenchment of automatable labour. Thus, developing and handling "automation tools" are done by the workforce itself. Sneha, who is a fresher in the industry, and is "passionate" about software coding, says that it is "impossible to be concerned about the implications of [their] work on other employees. We cannot afford to be sentimental during our work."

The two statements reveal the general nature of capitalist practices. While individualism and self-centeredness is actively encouraged among employees to discourage any attempt to unionise, the management is driven by systemic pressure to adopt technologies that cut costs and result in job losses (wage bill being a major 
incurred cost). This is endemic to capitalism, which is driven by the profit motive irrespective of whether the capitalist is ruthless or benevolent. The systemic tendencies to make labour redundant due to technological advancements without commensurate protection to the retrenched worker are less resisted by any significant collective formation by the employees. This reflects the lack of social control over technologies that are, in fact, socially produced.

Thus, what is essentially fostered within the workplace is an 'I versus them' binary. Nancy, who works at a prominent mass-recruiting company in Technopark says, "For them it is the profit motive; for me, it is about keeping my job". That is, the employee sees herself as an individual that must perform to meet the required standards imposed by the management and keep her job. While the employee is an 'I' who is concerned with improving her performance individually, the management is referred to as "them": those concerned about profits. It is evident that the individual has to negotiate with the manager class in the absence of collective bargaining. This is a characteristic of "neoliberal political rationality" (Brown 2015). But this is by no means exclusive to neoliberalism alone, as it is always in capital's interest to disenfranchise organised labour.

Capital's response to such labour-displacing technologies is also observed. As reports of labour displacement received public attention, IT companies have resorted to different strategies to cut the labour cost but avoid large-scale retrenchment. Four strategies were identified in this regard:

(a) Slow down the pace of hiring, but rely more on freshers, who will work for base salaries that have been more or less stagnant for a decade. This is because employees who had experience of over 15 years who occupy managerial posts were not in tune with new software, while new graduates were proficient. As Arora et al. (2001) note, the industry had encouraged promotion based on seniority rather than managerial capabilities. This means that the process of disintermediation, which is an aspect of downsizing, affects those who had high levels of work experience. This segment expressed the most anxiety: some confessed that they were studying for competitive exams, as they were unsure about the stability of their job. The IT industry retains a peculiar status where work experience can work against the worker.

(b) Assign more people to the 'bench' (freely deployable pool of labour) until a new project demands the skills of those employees. This is a precarious position for IT workers, as they are responsible for making themselves useful for the labour market. If they are unable to do so, they are persuaded or coerced into quitting the job, which the company masks as "involuntary attrition" (Narayan 2017).

(c) Rely more on software and computer science engineers during recruitment, and less on other disciplines. The IT labour market was hitherto able to absorb engineering graduates from all disciplines, including mechanical and civil streams, but the changing workplace demands that such a trend will most likely face roadblocks. This puts immediate pressure on the public sector, as most engineering graduates will resort to competitive exams for securing a stable job.

(d) Reduce the proportion of employees who are permanently on the payroll and rely more on contractual labour. Contractualisation is a feature of neoliberal capitalism and it is slowly becoming the norm in the IT industry. John, who works in a consultancy firm, intuitively came up with this statistical assessment: "Out of 10 people that are new recruits in a company, around 7 of 
them will be contract workers who belong to another service company. Earlier, there used to be only 3 or 4 contract workers in every 10 new recruits." During downturns, the contract workers are the most vulnerable in terms of job stability.

\subsection{Socio-spatial Distance and Scope for Unionisation}

This leads us to the second important point - that is how the average IT employee distinguishes themselves from the traditional working class. This can be analysed from different standpoints - cognitive, exhibitive, and spatial. We can define the cognitive standpoint as that which refers to the individual's perception and subjective self-valuation of their class identity. This depends on a host of factors, ranging from socioeconomic background to the nature of the workplace. Secondly, the individual exhibits distinct patterns of lifestyle and consumption patterns arising from the relatively higher purchasing power that is typical of the new middle class (Fernandes 2000). This is reflected, for example, in attire, food consumption, general demeanour, and so on, and can be called the exhibitive aspect. The third standpoint identified is spatial distance from the working class - through distancing oneself from the traditional working class in everyday interactions or through revealing a preference to live in areas that are habituated by similar professionals, or both. These different standpoints are not isolated, but are dependent on one another, as they organically constitute the everydayness of the IT employee who has aspirations of upward mobility.

From these standpoints, IT employees articulate their differences, which are also propagated in the media. This can be seen in the popular descriptions of the "techie" in cinema as well as in news media (Sathyendran 2017). The relative absence of such celebratory reports about non-IT workers contribute to the unconscious cultivation of the cognitive aspect of the distance of IT employees from the rest of the workers. Mahesh commented on this aspect as being artificially created by "media hype." While this can certainly be attributed to the 'sunrise' status of the industry in people's minds (though the industry is no longer a sunrise in reality), it has also contributed to the internalisation of this difference among IT employees.

At the same time, the IT workplace is distinguished from the traditional workplace based on the nature of the work, the workplace design, and the relationship with hierarchy. The nature of the work is such that most of the employees have to actively interact with foreigners, and hence require proficiency in communication skills. Employees were required to work night-shifts and overtime, if necessary. However, as Cheeran and Saji (2015) note, this has led to a disruption in employee work-life balance. Most of the employees surveyed were decently paid and have no complaints regarding salary payments. This is also because the company values performance: hence efficiency matters more than any other factor. Mahesh commented that "other workers, say, in the public sector, can afford to be lazy; we cannot." This reflects the attitude that the so-called "new middle class" (Fernandes 2000) has towards public sector jobs. Yet a significant majority of the employees revealed that they would prefer the employment security of public sector jobs. For them, the public sector is a secure space where one can afford to be less efficient, but get decently paid.

Workplace design also matters as the offices are considered to be more clean and compact where advanced technologies are being consistently used. Most companies lease out space in buildings in the IT park and there are often food courts, sports facilities, and other such facilities that are rarely found in the traditional 
workplace. Similarly, the architectural aesthetics and the landscape of IT parks are distinct, as are the surrounding areas. Near Technopark, for example, there is a high concentration of restaurants and cafes that offer north-Indian cuisine as well as other amenities targeting inter-state migrant employees. Such developments feed on the aspirations of employees and contribute to the exhibitive component.

Moreover, there is a construction boom in the region propelled by real estate developers to cater to the accommodation needs of the IT employees: this has driven land prices up in the so-called 'New Trivandrum' corridor. Thus, the urban space around IT parks is distinct in itself, creating a corridor, thereby transforming the landscape and in turn producing a 'new' city at the periphery of the old city. This also significantly contributes to the spatial distance from the rest of the workers.

Another significant factor is the employee's relationship with hierarchy. The workplaces are characterised as "informal". Amal, who self-identified as a progressive and is also a member of left-wing organisations, praised the "Western professionalism" that characterises the IT workplace. For Amal, since the "sir/madam" hierarchy that is a remnant of feudal relationships is absent in his office, it is more egalitarian. Sneha recounted the story of her friend in her company who was amused with the "friendliness" of the managers as opposed to his experience of strict hierarchy in the previous company he worked for, wherein even seniors who had who only had a year's more work experience' had to be called "sir". Sneha shared her personal experience wherein she found it uncomfortable when her superior gave her a deadline:

I remember how I did not like it when a senior manager asked me to get the work done on the next day. I am more comfortable working with managers whom I can regard as a friend. Thus, the workplace is most effective when it is similar to an informal college-like atmosphere.

Informal relationships are characteristic of the post-industrial neoliberal workplace where Taylorist management techniques are not efficient. This is interpreted as a transition from Fordism to Post-Fordism (MacKinnon and Cumbers 2014). Traditional forms of control are not effective in this new setting and hence management resorts to new methods that involve less authoritarianism. This is again due to the nature of work that demands more intellectual and creative labour than physical labour (Amorim 2014). At the same time, new forms of labour control are made possible with the advancement in technology. There are distinct layers of hierarchy within the management itself and the employee is often not involved in any direct contact with the top management of the company. Thus, the 'immediate informality' that employees experience cannot be interpreted as a sign of democracy or egalitarianism in the workplace.

This also leads us to the crucial question of unionisation within the IT industry. The industry is insulated from labour strikes and similar protests. The question that arises is whether unions have been able to adapt to the changing workplace conditions and assert their relevance to employees. To the question of whether unions are relevant in the industry, most employees posed the counter-question of how MNCs can have unions. The implicit notion is that employees are not allowed to form unions, though all citizens of India are accorded the fundamental right to form associations or unions under Article 19 (1) (c) of the Constitution of India (see Nizami 2017 for a discussion on labour laws and Indian IT industry). Yet it was obvious in 
the interviews that most of the employees were hostile towards the idea of unionisation. Four explicit reasons were stated for this:

1) The employees are treated well and they enjoy benefits commensurate to their performance. Thus, unions are not relevant in the IT industry.

2) Companies often have to deal with foreign clients, depending on the project. For the foreign clients, risk consideration is very important. Unless the work atmosphere is conducive, there will be no private investment.

3) If unions are formed, they may be political in nature. This will have unforeseeable consequences on employment generation. Private companies have relatively little fixed investment in Technopark. Hence, they can shut down the operations and leave the campus, if they feel that there is a tendency to unionise.

4) The government is also unlikely to support unions because they view IT as necessary for economic development.

Thus, most employees are concerned about companies leaving the park if they (employees) unionise. This reflects the disciplining mechanism of capital wherein sovereignty is being compromised for employment generation and other benefits that come to be associated with capitalists. While the state restricts itself without asserting its sovereignty from global capital, the employees restrict themselves from forming unions.

This is also an expression of hostility towards the labour-militancy of early postindependent Kerala. The recurrent sentiment was that because of the unique political climate of Kerala, unions should not be promoted. This is because IT is different the difference here primarily attributed to the footloose nature of capital in the IT industry. As such, the fixed investment is rather low - MNCs do not procure land here, but lease out space. Hence, they can shut down their operations and leave at the slightest hint of obstructionist politics. The employees feel that if politically charged unions operate in the industry, the companies will leave the park because clients are only concerned with efficiency and results. Rather than unionising to work for better terms, we see how they are willing to be disciplined by private capital. Union formation is equated with labour strikes - that in reality need not be the case. Collective bargaining does not necessitate obstructionist strikes.

Moreover, the management will always have an edge over the worker as the latter often agrees involuntarily to terms and conditions in employment contracts that they can be laid off once their performance declines. This gives the management power over employees in the event of unionisation. Participating in such activities can lead to 'blacklisting', hindering employment opportunities in other companies. This points to the coalition among capitalists, while at the same time discouraging any collective political movements among workers. "Even if the fired employee takes the issue to court, he or she will lose the case because of this provision", says John, who works in a sought-after service-providing company in Technopark. This reflects ambivalence towards the idea of organising. However, taking matters to the Labour Commissioner has been fruitful for retrenched employees in Chennai and Bengaluru (The Hindu Business Line 2017), which means that collectivisation is not impossible.

Thus, without getting overtly affiliated to political parties, 'collectives' are possible within the IT industry. Amal, who is affiliated with left-leaning political organisations, argues that the immediate aim is to start and energise "Employee Welfare Organisations" that can negotiate for retrenched workers. These organisations are slowly gaining acceptance among IT employees. For example, the organisation had successfully held a lecture on neoliberal economic policies that also pointed to the 
strategies used to politicise workers, without directly getting affiliated to political parties. One-third of the employees surveyed were not averse to the idea of a 'collective' within the company. This can gradually alter the cognitive aspect discussed earlier. It needs to be noted that the members of such organisations have no intention to challenge the structures that create this uncertainty in the first place. But they argue that some form of collectivisation is necessary so as to make IT jobs more secure. While there are unions in Bengaluru that are gaining importance, no such definitive trend is as yet visible in Thiruvananthapuram.

\section{Concluding remarks}

The discussion above shows that capitalism is pregnant with contradictions and that many of the emerging tensions in the industry originate in the conflict between the dynamic forces of production vis-à-vis stagnant relations of production. This outlook emphasising the advancement of capitalism adds to the existing literature on the emergence of the IT industry highlighting the role of the state and private (foreign) capital. The IT industry is significant in contemporary capitalism, as software packages developed within the sector can transform work in other sectors; for example, leading to labour displacement in other sectors like manufacturing. The present article examined how workers in the IT industry fared when it came to potential labour displacement within the industry in the event of structural transformations such as changes in business models and the adoption of new technologies.

The articulation of class position was given importance because class is not merely a theoretical category of analysis, but opens the practical possibility of organising for bettering the material conditions of workers. The article identified three distinct but related aspects that shape how IT workers distinguish themselves from traditional workers, viz. cognitive, exhibitive and spatial components. One merit of such an approach is that it opens up important political questions; for example, why technology has not been able to reduce working time. Technological advancement has not increased leisure, but only perpetuated job precarity in contemporary capitalism. Likewise, the lack of skilled workers, highlighted as a problem for employment generation, is conventionally understood as an individual issue of the worker and poor-quality education. While there is some merit in these arguments, we need to understand that the 'skills problem' is also systemic to capitalism precisely because of the way in which the system develops over time. The automation phase of capitalism expands itself by reinvesting surplus without commensurate employment generation, raising questions about the future of work.

In the context of Kerala, we see that there is a policy push towards the IT sector and that the state is keen to promote the region for its favourable investment climate. However, it is also seen that workers are anxious about the stability of their jobs. Contrary to celebratory claims about employment generation, the chief concern among workers is job insecurity. Without addressing the social relations in which production is organised, the labour process in which technologies are adopted to facilitate capital accumulation will remain undemocratic. The formation of 'collectives' becomes important in this context. The immediate aim of such organisations is to safeguard labour rights and pressurise the management to implement labour laws. This needs to be sustained as it provides a platform to politicise members and mitigate the asymmetries in employment relationships.

Outside established IT companies, there is also a state-sanctioned promotion of startup culture. The success of startups remains patchy, and they usually remain an 
abode for those who cannot find employment elsewhere, given the low employability of engineering graduates. Given capital's preference for software specialists, the ways in which the IT industry absorbs the surplus of engineering graduates in the state will have a major say in the labour market dynamic and the social stability of the state. Policymakers therefore need to be cautious in their push for knowledge-based employment generation within capitalism, as it might not be sustainable, given the contradictions endemic to the system.

\section{References}

Amorim, Henrique. 2014. Theories of Immaterial Labour: A Critical Reflection Based on Marx. Work Organisation, Labour and Globalisation 8 (1): 88-103.

Arora, Ashish, Vallampadugai S. Arunachalam, Jai Asundi, and Ronald Fernandes. 2001. The Indian Software Services Industry. Research Policy 30 (8): 1267-1287.

Barnes, Thomas. 2013. The IT Industry and Economic Development in India: A Critical Study. Journal of South Asian Development 8 (1): 61-83.

Bell, Daniel. 1976. The Coming of the Post-Industrial Society. The Educational Forum 40 (4): 574-579.

Brown, Wendy. 2015. Undoing the Demos: Neoliberalism's Stealth Revolution. Cambridge, MA: MIT Press.

Castells, Manuel. 1999. Information technology, globalization and social development. [Discussion paper] No. 114. United Nations Research Institute for Social Development. Geneva: UNRISD.

Chandrasekhar, CP and J. Ghosh. 2017. Indian IT hits a Speed Dump. Business Line, Nov 21.

Cheeran, Mariya T., and K. S. Saji. 2015. Appalling Insinuation of Software Jobs on Family Environment: A Study with Special Reference to IT Professionals in Kerala. Management and Labour Studies 40 (1-2): 145-158.

D'Costa, Anthony P. 2005. ICTs and Decoupled Development: Theories, Trajectories and Transitions. In Political economy and information capitalism in India, edited by Govindan Parayil, 11-34. London: Palgrave Macmillan.

Fernandes, Leela. 2000. Restructuring the new middle class in liberalizing India. Comparative Studies of South Asia, Africa and the Middle East 20 (1): 88-104.

Fuchs, Christian, and Marisol Sandoval. 2014. Digital Workers of the World Unite! A Framework for Critically Theorising and Analysing Digital Labour. tripleC: Communication, Capitalism \& Critique 12 (2): 486-563, Accessed April 10, 2020. https://www.triplec.at/index.php/tripleC/article/view/549

Heller, Patrick. 1995. From Class Struggle to Class Compromise: Redistribution and Growth in a South Indian State. The Journal of Development Studies 31 (5): 645-672.

llavarasan, Vigneswara P. 2008. Indian Software Workforce: A Labour Process View. In An Outpost of the Global Economy: Work and Workers in the India's Information Technology Industry, edited by Carol Upadhya and A.R Vasavi, 162-189. New Delhi: Routledge.

James, Al and Bhaskar Vira. 2012. Labour Geographies of India's New Service Economy. Journal of Economic Geography 12 (4): 841-875.

Kannan, K. P. 1998. Political Economy of Labour and Development in Kerala. Economic and Political Weekly L61-L70.

KPMG. 2011. "Non-linear Growth Model - Driving Profitability, Bolstering the Indian IT Industry". Accessed April 10, 2020. https://www.scribd.com/document/88303313/KPMGCll-Non-Linear-Models-IT-Driving-theNext-Phase-of-Growth-for-the-Indian-IT-Industry

Lakha, Salim. 1994. The New International Division of Labour and the Indian Computer Software Industry. Modern Asian Studies 28 (2): 381-408.

MacKinnon, Danny and Andrew Cumbers. 2014. Introduction to Economic Geography: Globalization, Uneven Development and Place. Harlow: Pearson Education. 
Ministry of Electronics and Information Technology. 2017. Annual Report 2016-17. Government of India. Accessed April 10, 2020. https://meity.gov.in/writereaddata/files/Annual Report 2017\%E2\%80\%9318.pdf

Narayan, Devika. 2017. Decoding Disruption: Lay-offs in the Software Industry. Economic \& Political Weekly 52 (22): 16-19.

NASSCOM. 2018. The IT-BPM Industry in India: Strategic Review: 2018 Executive Summary. Accessed April 10, 2020. https://community.nasscom.in/download.php?file=wpcontent/uploads/attachment/nasscom-itsr--executive-summary-2018.pdf

Nizami, Nausheen. 2017. Measuring the Gap between Labour Laws and Work in India's IT Industry and Policy Directions. The Indian Journal of Labour Economics 60 (2): 253-270.

Oommen, M.A. 1981. Mobility of Small Scale Entrepreneurs: A Kerala Experience. Indian Journal of Industrial Relations 17 (1): 65-87.

Parayil, Govindan. 2005. Introduction: Information Capitalism. In Political Economy and Information Capitalism in India, edited by Govindan Parayil, 1-10. London: Palgrave Macmillan.

Parthasarathy, Balaji 2005. The political economy of the computer software industry in Bangalore, India. In ICTs and Indian Economic Development: Economy, Work, Regulation, edited by Ashwani Saith and M. Vijayabaskar, 199-230. New Delhi: Sage Publications.

Remesh, Babu P. 2008. Shifting Trajectories: Work Organisation, Labour Relations and Mobilisation in Contemporary India. Noida: VV Giri National Labour Institute.

Rodrik, Dani and Arvind Subramanian. 2005. From "Hindu Growth" to Productivity Surge: The Mystery of the Indian Growth Transition. IMF Staff Papers 52 (2): 193-228.

Saraswati, Jyoti. 2013. A National Export-led Growth Plan: Lessons From the Software Industry. Economic and Political Weekly 48 (7): 21-24.

Saraswati, Jyoti. 2008. The Indian IT industry and Neoliberalism: The Irony of a Mythology. Third World Quarterly 29 (6): 1139-1152.

Sathyendran, Nita. 2017. Working Wonders. The Hindu. May 11, 2017. Accessed August 27, 2020. https://www.thehindu.com/society/ust-globals-swanky-newworkspace/article18425454.ece

Sreekumar, T. T. 2005. ICTs for the Rural Poor: Civil Society and Cyber-libertarian Developmentalism in India. In Political Economy and Information Capitalism in India, edited by Govindan Parayil, 61-87. London: Palgrave Macmillan.

Stevens, Andrew, and Vincent Mosco. 2010. Prospects for Trade Unions and Labour Organisations in India's IT and ITeS Industries. Work Organisation, Labour and Globalisation 4 (2): 39-59.

Technopark. 2018. Technopark Annual Report, 2017-18. Accessed April 10, 2020. https://cms.technopark.org/zcmspg/zupload/5363/dnl categ/1545112402616947604 Tec hnopark\%20Annual\%20Report\%2017-18.pdf

The Hindu Business Line. 2017. IT workers' union against Cognizant layoffs shift to Bengaluru. Accessed April 10, 2020. https://www.thehindubusinessline.com/info-tech/itworkers-union-against-cognizant-layoffs-shift-to-bengaluru/article9704992.ece

Thomas, Jayan Jose. 2005a. Kerala's Industrial Backwardness: A Case of Path Dependence in Industrialization? World Development 33 (5): 763-783.

Thomas, Jayan Jose. 2005b. Informational development in rural areas: Some evidence from Andhra Pradesh and Kerala. In Political economy and Information Capitalism in India, edited by Govindan Parayil, 109-132. London: Palgrave Macmillan.

Upadhya, Carol. 2008. Ethnographies of the Global Information Economy: Research Strategies and Methods. Economic and Political Weekly 43 (17): 64-72.

Upadhya, Carol. 2007. Employment, Exclusion and 'Merit' in the Indian IT industry. Economic and Political Weekly, 42 (20): 1863-1868. 
Upadhya, Carol. 2004. A New Transnational Capitalist Class? Capital Flows, Business Networks and Entrepreneurs in the Indian Software Industry. Economic and Political Weekly, 39(48): 5141-5151.

Xiang, Biao. 2005. Working with Uncertainty in the IT Industry. In Political Economy and Information Capitalism in India, edited by Govindan Parayil, 174-195. London: Palgrave Macmillan.

\section{About the Author}

\section{Aabid Firdausi MS}

Aabid Firdausi MS is a research student at the Tata Institute of Social Sciences, Mumbai. He is interested in studying the social and spatial dynamics of capitalism. 